Алієва А. Ю. [1; ORCID ID: 0000-0002-5086-5657], здобувач вищої освіти третього (освітньо-наукового) рівня

\footnotetext{
${ }^{1}$ Східноєвропейський національний університет імені Лесі Українки, м. Луцьк
}

\title{
КОНЦЕПТУАЛЬНІ ЗАСАДИ СТАЛОГО РОЗВИТКУ ТУРИСТИЧНО- РЕКРЕАЦІЙНОЇ СФЕРИ НА ЗАСАДАХ ІНКЛЮЗИВНОГО ЗРОСТАННЯ
}

Розкрито сутність та значення туристично-рекреаційної сфери. Доведено необхідність здійснення туристично-рекреаційної діяльності на засадах сталого розвитку. Це передбачає дотримання балансу між соціальними, економічними та екологічними результатами туристичнорекреаційної діяльності. Відповідь на питання досягнення перспектив сталого розвитку туристично-рекреаційної сфери знаходиться у площині інноваційного підходу до формування концептуальних засад, в основу яких покладено методологію інклюзивного зростання. Вона передбачає досягнення такого типу соціально-економічного зростання, який охоплює усі сфери життя суспільства та населення і дозволяє отримати відчутні для кожної людини результати. В основу методології формування концепції сталого розвитку туристично-рекреаційної сфери на засадах інклюзивного зростання покладено обґрунтування необхідності задоволення потреб усіх верств населення шляхом надання туристичнорекреаційних послуг за умови обмеженості ресурсів. Цільовим орієнтиром концепції сталого розвитку туристично-рекреаційної сфери на засадах інклюзивного зростання визначено залучення усіх верств населення (у тому числі малозабезпечених, жінок, осіб з обмеженими фізичними можливостями ін.) до виробничо-господарської, управлінської туристичної та рекреаційної діяльності як працівників, споживачів послуг, посередників, інвесторів, постачальників ресурсів, партнерів на всіх етапах ланцюга створення доданої вартості. Реалізація концепції сталого розвитку туристично-рекреаційної сфери на засадах інклюзивного зростання сприяє розширенню можливостей для забезпечення рівного доступу до ринків туристично-рекреаційних послуг і туристично-рекреаційних ресурсів. Концептуальні засади дозволяють сформувати наукову базу для розробки стратегічних пріоритетів та організаційно-економічного механізму забезпечення цього процесу на засадах інклюзивного зростання.

Ключові слова: туристично-рекреаційна сфера; сталий розвиток; інклюзивне зростання; туристично-рекреаційні послуги; стратегічні пріоритети розвитку туристично-рекреаційної сфери. 
Постановка проблеми. Сталий розвиток сфери туристичнорекреаційних послуг $є$ важливим показником якості життя та рівня людського розвитку, має важливе економічне та соціальне значення у суспільстві та базується на таких основних характеристиках, як масовість, інтегрованість, екологічність, інклюзивність, соціальна ефективність, економічна доцільність.

Для забезпечення сталого розвитку туристично-рекреаційної сфери як динамічної форми міжнародної торгівлі послугами та високорентабельної галузі національної економіки, необхідним $\epsilon$ формування ефективних і раціональних взаємодій серед усіх учасників ринку туристичних і рекреаційних послуг на засадах комплексного підходу та системного вирішення питань розвитку альтернативних способів досягнення конкурентних переваг бізнесу від туристичної та рекреаційної діяльності.

Аналіз досліджень та публікацій. Традиційні підходи, за якими туризм і рекреація розглядаються вченими в контексті їх розвитку як галузі (сектору) економіки чи просторово-територіального утворення (Ю. О. Вєдєнін, Н. В. Коленда, В. Ф.Кифяк, О.С.Любіцева, Т.І.Ткаченко, С. К. Харічков, Л. М. Черчик, В. В. Шмагіна та ін.) практично вичерпали себе в сенсі конструктивного бачення перспектив їх розвитку та зрештою їх місії і завдань у подоланні складних протиріч сучасного світу [1, С. 35].

Аналіз підходів вітчизняних і зарубіжних науковців до трактування понять «туризм» i «рекреація» дозволив зробити висновок про «необхідність їх комплексного сприйняття, як єдиної сфери, мета котрої полягає у відновленні та розвитку життєвих сил людини» [2, С.6]. Туристична та рекреаційна діяльності є видами господарської діяльності з організації туризму, екскурсій, дозвілля, відпочинку, курортно-профілактичного лікування, оздоровлення. В науковій літературі домінує диференційований підхід до визначення туристичної та рекреаційної діяльності. Пропонуємо туристичнорекреаційну сферу визначати як цілісний напрям діяльності 3 надання туристично-рекреаційних послуг, що «зорієнтований на відновлення фізичних і психічних сил населення, його духовне та культурне збагачення» [3, С. 33].

Концепція сталого розвитку туристично-рекреаційної сфери «базується на доктрині сталого розвитку, яка є сукупністю ідей, концепцій, положень та постулатів різних наук і спрямована на зміну стосунків людини і природи для розширення можливостей економічного зростання та на створення скоординованої глобальної стратегії виживання людства, орієнтованої на збереження i відновлення природних спільнот у масштабах, необхідних для повернення до меж господарської місткості біосфери» [4]. 
Згідно з трактуванням Світової організації туризму, сталий розвиток туристичної сфери полягає у врахуванні його поточних та майбутніх економічних, соціальних та екологічних наслідків її діяльності, задовольняючи зростаючі потреби туристів, галузі, довкілля, громади [5]. 3 огляду на зростаюче значення раціонального використання, охорони та відтворення природних ресурсів для сектору подорожей, туризму, відпочинку, оздоровлення, звернемо увагу на необхідність здійснення туристично-рекреаційної діяльності на засадах сталого розвитку.

Невирішені раніше частини загальної проблеми. Відповідь на питання досягнення перспектив сталого розвитку туристичнорекреаційної сфери знаходиться у площині інноваційного підходу до формування концептуальних засад, в основу яких покладено методологію інклюзивного зростання, що передбачає досягнення такого типу соціально-економічного зростання, який охоплює усі сфери життя суспільства та населення і дозволяє отримати відчутні для кожної людини результати.

Постановка завдання. Завданням статті $\epsilon$ розкриття методології формування концептуальних засад та стратегічних пріоритетів сталого розвитку туристично-рекреаційної сфери на засадах інклюзивного зростання.

Основні результати дослідження. Ефективною методологічною основою дослідження сталого розвитку туристично-рекреаційної сфери (рис. 1) є використання системного підходу, який дозволяє, 3 одного боку, виявити структуру його організаційно-економічного забезпечення та різноманітні внутрішні зв'язки, а $з$ іншого визначити чинники і передумови, що впливають на його розвиток, а також характер взаємодії із зовнішнім середовищем. Цільова функція сталого розвитку туристично-рекреаційної сфери як еколого-соціально-економічної системи полягає у виробленні та реалізації соціально-корисного продукту - туристично-рекреаційних послуг, що супроводжується отриманням соціально-економічного результату у вигляді прибутку від туристично-рекреаційної діяльності та створення робочих місць.

На відміну від інших концептуальних поглядів на розширення економічних можливостей і рівного доступу всіх верств населення, «інклюзивне зростання - це концепція, яка забезпечує справедливі можливості та рівноправ'я для економічних учасників, що супроводжується вигодами, принесеними кожному сектору економіки та різним верствам суспільства. 


\section{Методологія формування концептуальних засад та стратегічних пріоритетів сталого розвитку туристично-рекреаційної сфери}

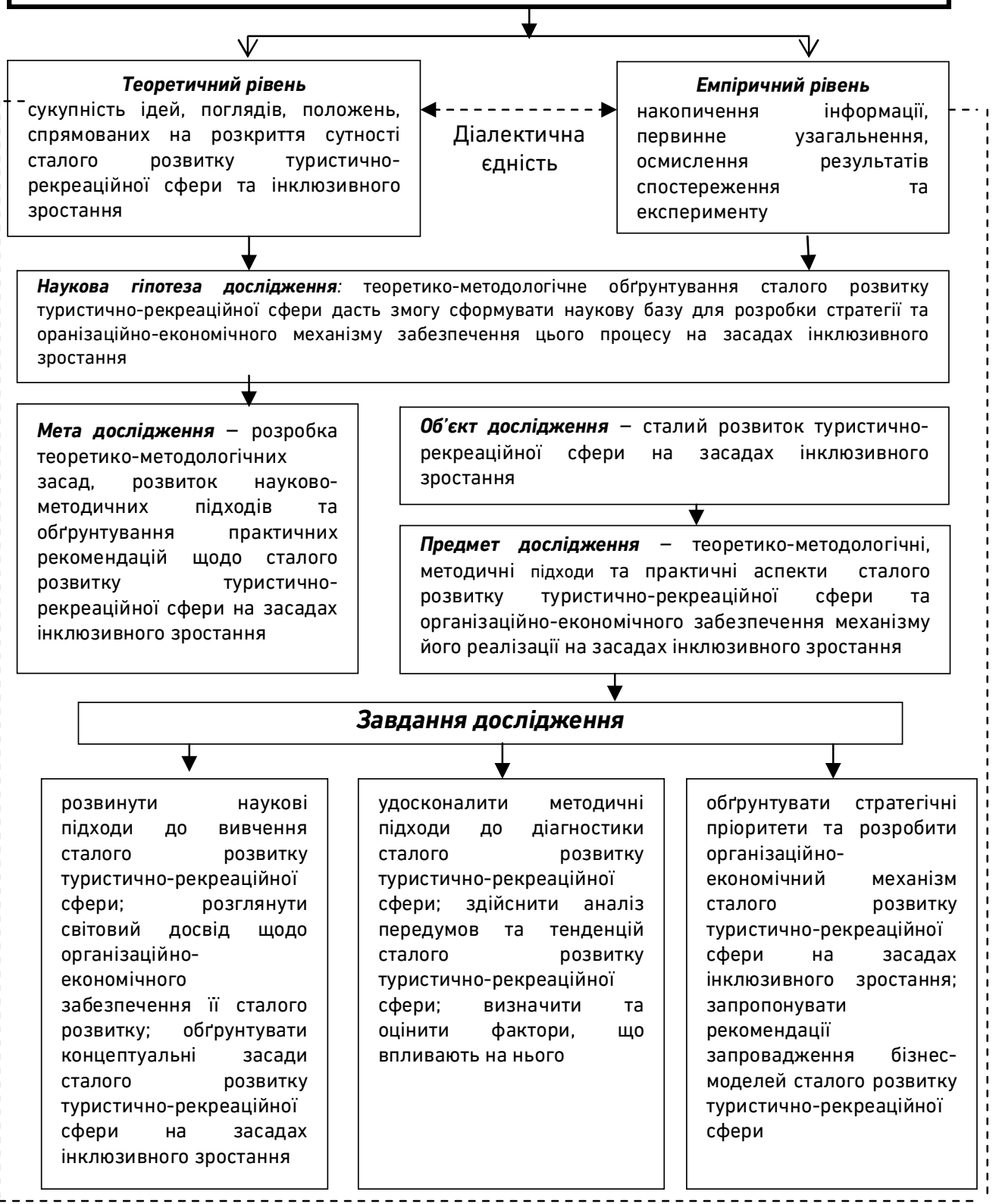

Рисунок. Методологія формування концептуальних засад та стратегічних пріоритетів сталого розвитку туристично-рекреаційної сфери Джерело : побудовано автором

Даний підхід розширює традиційні моделі економічного зростання та включає зосередження уваги на рівності здоров'я, людського капіталу, екологічного стану довкілля, соціального 
захисту та продовольчої безпеки як чинників світової безпеки в широкому розумінні» [6]. Інклюзивне зростання як самостійна концепція зосереджена навколо взаємодії зазначених вище економічних категорій - економічного зростання, бідності, нерівності доходів і можливостей. На думку Прогнімак О.Д., «інклюзивне зростання - це зростання, яке дозволяє залучити більшу частину трудових ресурсів до ефективної економічної діяльності, завдяки чому забезпечити більшій частині населення більш високий рівень життя. Значна увага приділяється розподільчим аспектам добробуту і доданню зростанню антидискримінаційної спрямованості. Люди можуть отримувати вигоди від економічного зростання як пасивні учасники, не приймаючи активної участі у збільшенні доходу або ВВП, а лише завдяки політиці перерозподілу. Це є досить поширеною практикою у більшості країн, і не тільки в бідних і тих, що розвиваються» [7].

Інклюзивне зростання представляє собою «зростання, що не лише створює нові економічні можливості, а й забезпечує рівний доступ до них для всіх верств населення, особливо для уразливих його представників» [8]. Виходячи з цього, формуються поняття інклюзивного туризму та інклюзивної рекреації, що характеризують розширення можливостей використання та вільний доступ до туристичних і рекреаційних послуг осіб з обмеженими фізичними можливостями.

Звернемо увагу, що цілі інклюзивного розвитку в Європейському Союзі є стратегічним пріоритетом програми «європа - 2020», де зазначається, що «зростання має бути інтелектуальним, стійким і інклюзивним при залученні до відповідних процесів усіх секторів економіки, усіх верств суспільства для досягнення високого рівня зайнятості, продуктивності і соціальної єдності» [9]. Загалом у сучасних умовах ідея інклюзивності активно запроваджується у програмних документах урядів країн світу, міжнародних організацій, громадських спільнот. Зокрема, у підсумковому документі саміту ООН 2015 року «Перетворення нашого світу: порядок денний у сфері сталого розвитку до 2030 р.» тема інклюзивності присутня у формулюванні практично усіх 17 затверджених ним Цілей сталого розвитку (ЦСР), а в окремих 3 них прямо вживається термін «інклюзивний», поданий в українському перекладі словами як «всеохоплюючий», «загальний». В Україні забезпеченню реалізації ЦСР присвячена Національна доповідь «Цілі Сталого Розвитку: Україна», підготовлена Міністерством економічного розвитку та схвалена Міжвідомчою робочою групою високого рівня для організації процесу імплементації ЦСР для України [10]. 
у публікаціях, присвячених дослідженню інклюзивного розвитку та інклюзивного зростання, найчастіше розглядаються, як зазначено у роботах [11-13], такі актуальні завдання, що $\epsilon$ характерними для функціонування туристично-рекреаційної сфери в сучасних умовах:

- вирішення проблем найбільш маргіналізованих верств суспільства (бідних, уразливих, соціально незахищених категорій громадян, жінок, літніх людей тощо) у недискримінаційний щодо них спосіб з метою зменшення соціальної нерівності;

- «оздоровлення» збиткових видів економічної діяльності та депресивних територій, зокрема, приміських районів, сільських територій, задля сприяння створення нових робочих місць, розширення місць прикладання праці, забезпечення достатньої мережі об'єктів інфраструктури шляхом залучення інвестиції та інновацій, різноманітних програм розвитку;

- створення рівних можливостей участі різних верств населення у суспільних процесах;

- цілеспрямоване стимулювання розвитку потенціалу маргінальних груп населення для реалізації наданих можливостей;

- нарощування знань місцевого населення шляхом організації ефективного освітнього процесу;

- перерозподіл соціальних переваг, зокрема у громадському транспорті, енергетичному секторі, сфері медичних та освітніх послуг;

- децентралізація управління та демократичний стиль менеджменту, відхід від використання суто технократичних підходів;

- визнання і збереження традицій, звичаїв;

- розширення можливостей самозабезпечення

та самозайнятості для найуразливіших верств населення.

Загалом поняття інклюзивного розвитку має широке значення, i стосується усіх сфер людської діяльності, у тому числі і туристичнорекреаційної сфери. Становлення поняття «інклюзивний розвиток туристично-рекреаційної сфери» відбувається у процесі конкретизації теоретичних концепцій сталого розвитку туристичних та рекреаційних підприємств, бізнес-моделей їх розвитку.

На нашу думку, сталий розвиток туристично-рекреаційної сфери на засадах інклюзивного зростання передбачає залучення усіх верств населення (у тому числі малозабезпечених, у яких середньомісячний сукупний дохід нижчий від прожиткового 
мінімуму, жінок, осіб з обмеженими фізичними можливостями, ін. ) до виробничо-господарської, управлінської туристичної та рекреаційної діяльності як працівників, споживачів послуг, посередників, інвесторів, постачальників ресурсів, партнерів на всіх етапах ланцюга створення доданої вартості. Відповідно працівники, споживачі послуг, посередники, інвестори, постачальники ресурсів, партнери виступають учасниками інклюзивного розвитку підприємств туристично-рекреаційної сфери.

Основною концептуальною ідеєю виступає забезпечення інтегрованого підходу до розширення можливостей задоволення потреб усіх верств населення, зокрема малозабезпечених i соціально незахищених, за умов обмеженості ресурсів шляхом забезпечення рівного доступу до туристично-рекреаційних послуг i туристично-рекреаційних ресурсів.

Цілі сталого розвитку туристично-рекреаційних послуг на засадах інклюзивного розвитку наступні:

- соціальні (підвищення рівня зайнятості та самозайнятості населення; подолання бідності; розвиток туристично-рекреаційної інфраструктури; підвищення якості надання туристичнорекреаційних послуг; забезпечення життєдіяльності міського та сільського населення, збереження традицій та звичаїв);

- економічні (збільшення ВВП; збільшення місцевого, регіонального та національного бюджетів, підвищення добробуту; залучення інвестицій шляхом зростання заощаджень; підвищення конкурентоспроможності продукції та послуг; зростання експорту послуг; зменшення ризику фіаско ринку);

- екологічні (розвиток екологічної інфраструктури; розвиток циркулярної економії; зменшення деструктивного впливу на довкілля; охорона та відтворення природно-ресурсного потенціалу; підвищення енергоефективності; запровадження зелених технологій; запобігання кліматичних змін; підвищення екологічної свідомості).

Завдання сталого розвитку туристично-рекреаційної сфери на засадах інклюзивного зростання - це підвищення якості та конкурентоспроможності туристично-рекреаційного продукту; раціональне використання туристично-рекреаційного потенціал; створення умов для розвитку ефективних моделей туристичнорекреаційної індустрії тощо.

Висновки та пропозиції. Отже, цільовим орієнтиром концепції сталого розвитку туристично-рекреаційної сфери на засадах інклюзивного зростання $€$ розширення можливостей задоволення 
потреб усіх верств населення, зокрема малозабезпечених i соціально незахищених, за умов обмеженості ресурсів шляхом забезпечення рівного доступу до туристично-рекреаційних послуг i туристично-рекреаційних ресурсів.

1. Гулич О.І. Перспективи України та ї̈ регіонів у реалізації соціогуманістичної парадигми розвитку туристично-рекреаційного сектору економіки. Регіональна економіка. 2014. № 7. С. 76-85. 2. Котенко Т. М. Соціальний вимір розвитку рекреації та туризму : автореф. дис. ... канд. екон. наук: 08.00.07 / Ін-т демографії та соц. досліджень ім. М. В. Птухи НАН України. Київ, 2016. 20 с. 3. Новикова В.І. Рекреаційні послуги: класифікація та розвиток у Черкаській області. Український географічний журнал. 2009. № 4. С. 33-39. 4. Заячковська Г. Концепція сталого розвитку сфери туризму як засіб післякризового відновлення галузі. Вісник Тернопільського національного економічного університету. 2011. № 5-2. С. 345-350. 5. Sustainable Development. World Tourism Organization. URL: https://www.unwto.org/ru/node/79 (дата звернення: 20.04.2020). 6. Ranieri R., Ramos R. A. Inclusive Growth: Building up a Concept. International Policy Centre for Inclusive Growth. Working Paper. Brazil. 2013. No 104. URL: https://ipcig.org/pub/IPCWorkingPaper104.pdf (дата звернення: 15.04.2020). 7. Прогнімак О.Д. Інклюзивний розвиток України: перешкоди vs перспективи. Економічний вісник Донбасу. 2018. №1 (51). С. 187-197. 8. Цимбалюк І. 0. Інклюзивний розвиток регіону в умовах фінансової децентралізації: теорія, методологія, практика: монографія. Луцьк: Вежа-Друк, 2019. 340 с. 9. Europe 2020. A European strategy for smart, sustainable and inclusive growth. European Commission. Brussels, $2010 . \quad 34 \mathrm{p} . \quad$ URL: http://ec.europa.eu/europe2020/index_en.htm (дата звернення: 17.04.2020). 10. Цілі Сталого Розвитку: Україна. Національна доповідь. Міністерство економічного розвитку і торгівлі України. 2017. URL: http://www.ua.undp.org/content/ukraine/uk/home/ library/sustainable-development-report/sustainable-development-goals--2017-

basseline-nationalreport.htm (дата звернення: 29.04.2020). 11. Pouw N., Gupta J. Inclusive Development: A Multi-Disciplinary Approach. Current Opinion in Environmental Sustainability. 2017.

URL: https://www.researchgate.net/profile/Nicky_Pouw/publication/315265627_ Inclusive_Development_A_Multi-Disciplinary_Issue/links/5a0e043baca2724 4d28586cd/Inclusive-Development-A-Multi-Disciplinary-Issue.pdf (дата звернення: 22.04.2020). 12. Хомюк Н. Л. Диверсифікація розвитку сільських територій в умовах децентралізації: монографія. Луцьк: Вежа-Друк, 2019. 320 с. 13. Павліха Н. В., Скороход І.С. Екологізація туристичної сфери: інноваційний підхід. Вісник ДІТБ. 2005. № 9. С. 185-189.

\section{REFERENCES:}

1. Hulych 0. I. Perspektyvy Ukrainy ta yii rehioniv u realizatsii sotsiohumanistychnoi paradyhmy rozvytku turystychno-rekreatsiinoho sektoru ekonomiky. Rehionalna ekonomika. 2014. № 7. S. 76-85. 2. Kotenko T. M. Sotsialnyi vymir rozvytku rekreatsii ta turyzmu: avtoref. dys. ... kand. ekon. nauk: 08.00.07 / In-t demohrafii ta sots. doslidzhen im. M. V. Ptukhy NAN Ukrainy. Kyiv, 2016. 20 s. 3. Novykova V.I. Rekreatsiini posluhy: klasyfikatsiia ta rozvytok u Cherkaskii oblasti. Ukrainskyi heohrafichnyi zhurnal. 2009. № 4. S. 33-39. 4. Zaiachkovska, H. Kontseptsiia staloho 
rozvytku sfery turyzmu yak zasib pisliakryzovoho vidnovlennia haluzi. Visnyk Ternopilskoho natsionalnoho ekonomichnoho universytetu. 2011. № 5-2. S. 345-350. 5. Sustainable Development. World Tourism Organization. URL: https://www.unwto.org/ru/node/79 (data zvernennia: 20.04.2020). 6. Ranieri R., Ramos R. A. Inclusive Growth: Building up a Concept. International Policy Centre for Inclusive Growth. Working Paper. Brazil. 2013. No 104. URL: https://ipcig.org/pub/IPCWorkingPaper104.pdf (data zvernennia: 15.04.2020). 7. Prohnimak O. D. Inkliuzyvnyi rozvytok Ukrainy: pereshkody vs perspektyvy. Ekonomichnyi visnyk Donbasu. 2018. №1(51). S.187-197. 8. Tsymbaliuk I. 0. Inkliuzyvnyi rozvytok rehionu $v$ umovakh finansovoi detsentralizatsii: teoriia, metodolohiia, praktyka : monohrafiia. Lutsk: Vezha-Druk, 2019. 340 s. 9. Europe 2020. A European strategy for smart, sustainable and inclusive growth. European Commission. Brussels, 2010. 34 p. URL: http://ec.europa.eu/europe2020/index_en.htm (data zvernennia: 17.04.2020). 10. Tsili Staloho Rozvytku: Ukraina. Natsionalna dopovid. Ministerstvo ekonomichnoho rozvytku i torhivli Ukrainy. 2017. URL: http://www.ua.undp.org/content/ukraine/uk/home/ library/sustainable-development-report/sustainable-development-goals--2017-

basseline-nationalreport.htm (data zvernennia: 29.04.2020). 11. Pouw N., Gupta J. Inclusive Development: A Multi-Disciplinary Approach. Current Opinion in Environmental Sustainability. 2017.

URL :

https://www.researchgate.net/profile/Nicky_Pouw/publication/315265627_

Inclusive_Development_A_Multi-Disciplinary_Issue/links/5a0e043baca2724

4d28586cd/Inclusive-Development-A-Multi-Disciplinary-Issue.pdf (data zvernennia: 22.04.2020). 12. Khomiuk N. L. Dyversyfikatsiia rozvytku silskykh terytorii v umovakh detsentralizatsii : monohrafiia. Lutsk: Vezha-Druk, 2019. 320 s. 13. Pavlikha N. V., Skorokhod I. S. Ekolohizatsiia turystychnoi sfery: innovatsiinyi pidkhid. Visnyk DITB. 2005. № 9. S. 185-189.

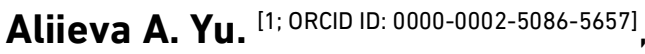
Post-graduate Student

${ }^{1}$ Lesya Ukrainka Eastern European National University, Lutsk

\section{CONCEPTUAL PRINCIPLES OF THE TOURIST AND RECREATIONAL SPHERE SUSTAINABLE DEVELOPMENT ON THE PRINCIPLES OF INCLUSIVE GROWTH}

The essence and significance of the tourist and recreational sphere are revealed. The necessity of tourist and recreational activities on the basis of sustainable development is proved. This implies a balance between social, economic and environmental results of tourism and recreation. The answer to the question of achieving prospects for tourism and recreation sustainable development is in the plane of an innovative approach to the formation of conceptual foundations, which are based on the methodology of inclusive growth. It envisages the achievement of this type of socioeconomic growth, which covers all spheres of society and population, and 
allows to obtain tangible results for everyone. The methodology of forming the concept of the tourist and recreational sphere sustainable development on the basis of inclusive growth, is based on the justification of the need to meet the all segments of the population needs by providing tourist and recreational services with limited resources. The target of the concept of the tourist and recreational sphere sustainable development on the basis of inclusive growth is the involvement of all segments of the population (including poor, women, people with disabilities, etc.) in industrial, economic, tourist and recreational activities as workers, consumers, intermediaries, investors, resource suppliers, partners at all stages of the value chain. Implementation of the concept of the tourist and recreational sphere sustainable development on the basis of inclusive growth contributes to the expansion of opportunities to ensure equal access to the markets resources of tourist and recreational services. Conceptual principles allow to form a scientific basis for the development of strategic priorities and organizational and economic mechanism to ensure this process on the basis of inclusive growth.

Keywords: tourist and recreational sphere; sustainability; inclusive growth; tourist and recreational services; strategic priorities for the development of tourism and recreation.

Алиева А. Ю. [1; ORCID ID: 0000-0002-5086-5657], соискатель высшего образования третьего (образовательнонаучного) уровня

${ }^{1}$ Восточноевропейский национальный университет имени Леси Украинки, г. Луцк

\section{КОНЦЕПТУАЛЬНЫЕ ОСНОВЫ УСТОЙЧИВОГО РАЗВИТИЯ ТУРИСТСКО-РЕКРЕАЦИОННОЙ СФЕРЫ НА ОСНОВЕ ИНКЛЮЗИВНОГО РОСТА}

Раскрыты сущность и значение туристско-рекреационной сферы. Обоснована необходимость осуществления туристско-рекреационной деятельности на принципах устойчивого развития. Это предполагает соблюдение баланса между социальными, экономическими и экологическими результатами туристско-рекреационной деятельности. Ответ на вопрос достижения перспектив устойчивого развития туристско-рекреационной сферы находится в плоскости инновационного подхода к формированию концептуальных основ, в основу которых положена методология инклюзивного роста. Она предполагает достижение такого типа социально-экономического роста, который охватывает все сферы жизни общества и населения и позволяет получить ощутимые для каждого человека результаты. В основу методологии формирования концепции устойчивого развития туристско- 
рекреационной сферы на основе инклюзивного роста положено обоснование необходимости удовлетворения потребностей всех слоев населения путем предоставления туристско-рекреационных услуг при условии ограниченности ресурсов. Целевым ориентиром концепции устойчивого развития туристско-рекреационной сферы на основе инклюзивного роста определено привлечение всех слоев населения (в том числе малообеспеченных, женщин, лиц с ограниченными физическими возможностями и др.) в производственно-хозяйственной, управленческой туристической и рекреационной деятельности как работников, потребителей услуг, посредников, инвесторов, поставщиков ресурсов, партнеров на всех этапах цепочки создания добавленной стоимости. Реализация концепции устойчивого развития туристскорекреационной сферы на основе инклюзивного роста способствует расширению возможностей для обеспечения равного доступа к рынкам туристско-рекреационных услуг и туристско-рекреационных ресурсов. Концептуальные основы позволяют сформировать научную базу для разработки стратегических приоритетов и организационноэкономического механизма обеспечения этого процесса на основе инклюзивного роста.

Ключевые слова: туристско-рекреационная сфера; устойчивое развитие; инклюзивный рост; туристско-рекреационные услуги; стратегические приоритеты развития туристско-рекреационной сферы. 